
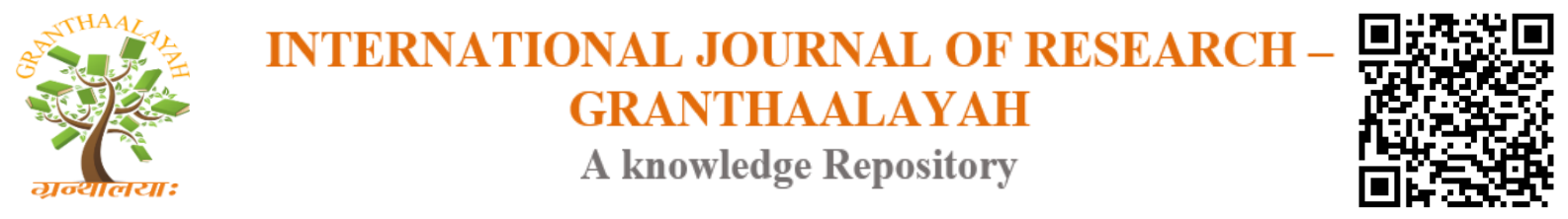

Social

\title{
ROLE OF SOCIAL GROUPS TO ENHANCE AWARENESS ABOUT ENVIRONMENT CONSERVATION
}

\author{
Dr. Paras Jain ${ }^{* 1}$, Shivangi Jain ${ }^{2}$ \\ ${ }^{* 1}$ Director, Silicobyte Katni Degree College, Dikshabhumi Campus, Katni (M.P), India \\ ${ }^{2}$ OSD, Silicobyte Katni Degree College, Dikshabhumi Campus, Katni (M.P), India
}

\begin{abstract}
Environment is degrading at a much faster pace than our imagination. Most of this pollution is caused by human activities. To protect and manage environment it is imperative to have a sound environmental awareness. Social service groups are creating awareness among people to protect it. Present study is focused on finding of awareness among villagers regarding environment conservation and comparison of villagers of villages adopted by social groups with villagers of villages not adopted by social groups.
\end{abstract}

Keywords: Environment; Social Groups; Conservation; NGO’s; Awareness.

Cite This Article: Dr. Paras Jain, and Shivangi Jain. (2017). "ROLE OF SOCIAL GROUPS TO ENHANCE AWARENESS ABOUT ENVIRONMENT CONSERVATION." International Journal of Research - Granthaalayah, 5(11), 50-52.

\section{Introduction}

The Government of India has issued its National Policy on voluntary sector and the main objet of the policy is to encourage, enable and empower an independent, creative and effective voluntary sector, with diversity in form and function, so that it can contribute to the social, cultural and economic advancement of people of India. Social groups as non-profit development organization, has been promoting environmental improvement initiatives. Social groups are active in environmental education, biodiversity conservation, solid waste management, and eco conservation. The Fundamental objective of social groups is to act as catalyst in bringing about local, national and international initiative and community participation in overall improvement. The way natural environment works and how humans should behave to manage ecosystem to sustain environment is part of the environmental awareness. It imparts the required skills and expertise to handle the associated challenges.

The social developmental group emphasizes the development of environment conservation practices following the incremental elaboration of environmental knowledge. The self-organizing process, facilitated by knowledge development and learning, has the potential to increase the 
resilience of resource use systems. Hence, conservation knowledge can develop through a combination of long-term ecological understanding and learning from crises and mistakes.

The NGO's constitute a worldwide network interacting with governments and intergovernmental organization in shaping international environmental policies: as creating awareness among the public on current environmental issues and solutions, facilitating the participation of various categories on environmental issues and conducting participatory rural appraisal. NGOs are involved in the protection of human rights to have a clean environment, protect the natural resources and generate data on natural resources. Social groups contribute to analyze and monitoring of environmental quality, transferring information through newsletters, brochures, articles, audio visuals, etc. These groups organize seminars, lectures and group discussion for promotion of environmental awareness and help the villages' administrative officials in preparation and execution of projects on environmental protection.

\section{Objective of Study}

- Finding of environment conservation awareness among villagers of village adopted by social groups.

- Finding of environment conservation awareness among villagers of village not adopted by social groups.

\section{Hypothesis}

1) There is significant environment conservation awareness among villagers of village adopted by social groups.

2) There is no significant environment conservation awareness among villagers of village not adopted by social groups.

\section{Methodology}

Descriptive survey method was used for present study. 600 villagers with 21 to 40 years age belonging 20 villages were selected randomly as sample. 15 male and 15 female from every village were taken in sample. All villagers were tested for environment conservation awareness using a self-prepared test paper. Collected data was tabulated and analyzed using mean, standard deviation and $\mathrm{t}$ value as statistical tools.

\section{Finding and Analysis}

Table 1: Status of Awareness among Villagers about Environment Conservation

\begin{tabular}{|c|c|c|c|c|}
\hline Category & Gender & Mean Value & Standard Deviation & t Value \\
\hline \multirow{2}{*}{$\begin{array}{l}\text { Villages Adopted } \\
\text { By Social Groups }\end{array}$} & Male & 57 & 1.34 & \multirow[t]{2}{*}{0.86} \\
\hline & Female & 51 & 1.06 & \\
\hline \multirow{2}{*}{$\begin{array}{l}\text { Villages not } \\
\text { Adopted By } \\
\text { Social Groups }\end{array}$} & Male & 43 & 1.21 & \multirow[t]{2}{*}{0.81} \\
\hline & Female & 37 & 0.98 & \\
\hline
\end{tabular}




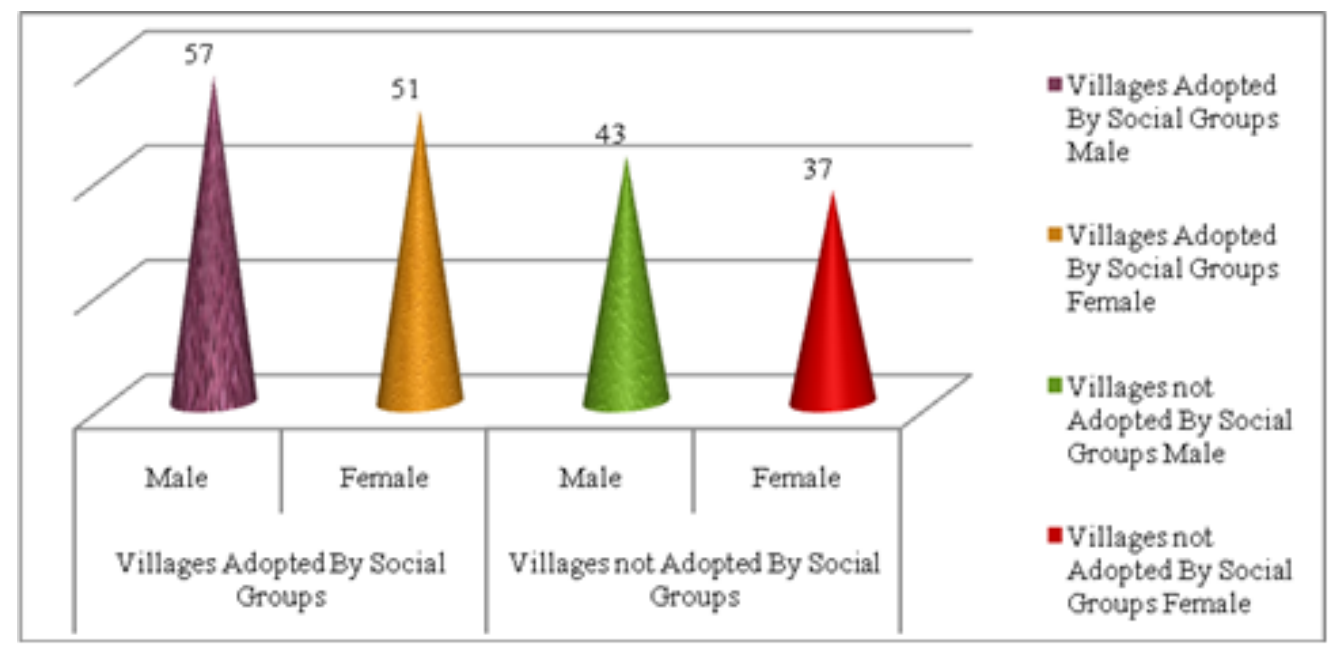

Chart 1: Status of Awareness among Villagers about Environment Conservation

Data table shows that male persons of villages adopted by social service groups have mean value 57 with standard deviation 1.34. Female of these villages exhibit mean value 51 with standard deviation 1.06. Calculated $t$ value is 0.86 . Thus hypothesis 1 , there is significant environment conservation awareness among villagers of village adopted by social groups is accepted.

Among villagers of villages not adopted by social groups, awareness found less. Male got mean value 43 with standard deviation 1.21 and female got mean value 37 with standard deviation 0.98. $\mathrm{t}$ value is calculated as 0.81 . Hence hypothesis 2 , there is no significant environment conservation awareness among villagers of village not adopted by social groups is accepted.

\section{Conclusion}

The main focus of the social groups working in this field is to impart knowledge, create awareness, inculcate an attitude of concern and provide necessary skill to handle the environment and environmental challenges. Social groups are doing sincere efforts to bring social awareness about environment conservation.

\section{References}

[1] Hungerford, H.R., Volk, T.L., Changing Learner Behavior through Environmental Education, the Journal of Environmental Education, Volume 21, Issue 3, 1990.

[2] Berkes, F., \& Turner, N.J., Knowledge, Learning and the Evolution of Conservation Practice for Social-Ecological System Resilience, Human Ecology, August 2006.

[3] Pretty, J., Social Capital and the Collective Management of Resources, Science, Vol. 302, Issue 5652, 12 December 2003.

[4] Brown, R., A study on Non-Governmental Organization's (NGO's) in Protecting The Environment, http://www.legalservicesindia.com, 28 Nov. 2012.

[5] Kaur, R., Why Environmental Education is the need of the day, https://www.mapsofindia.com, 8 July 2014.

*Corresponding author.

E-mail address: parasjainkatni@ gmail.com 